\title{
INSTAGRAM SEBAGAI MEDIA PEMBENTUK PERSONAL BRANDING
}

\author{
${ }^{1}$ Haryadi Mujianto, ${ }^{2}$ Zikri Fachrul Nurhadi, ${ }^{3}$ Kenny Kharismawati \\ 1,2,3 Program Studi Ilmu Komunikasi, Universitas Garut \\ haryadimujianto@uniga.ac.id
}

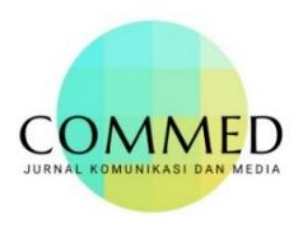

Diterima : 08 Desember 2020; Review : 03 Januari 2021; Direvisi Author : 20 Januari 2021; Terbit : 14 Februari 2021

\begin{abstract}
This study discusses Instagram as a personal branding media. The purpose of this research is to describe the factors that established personal branding. The research method used in this research is descriptive qualitative research. The informants in this study consisted of 3 celebgrams at the Garut City, Informants are determined by purposive sampling. The results of this study are, branding on Instagram social media is an effort to present information, messages and impressions through the activities carried out. Personal branding that is formed based on the main dimensions of the formation of personal branding that they show on each Instagram account including style, caption, special abilities or competences in a certain area controlled by celebrities and selfstandards can form personal branding through a polish and well communication method.
\end{abstract}

Keywords: Personal Branding, Instagram, Celebgram

\section{PENDAHULUAN}

Membentuk suatu Personal Branding menjadi cara untuk meningkatkan nilai jual seseorang, terlihat dari skill, kepribadian, dan karakter unik seseorang untuk kemudian dapat membungkusnya menjadi sebuah identitas yang memiliki kekuatan lebih dibandingkan dengan yang lain. Personal branding secara tidak langsung telah dibangun oleh seseorang individu dari sebuah perkerjaan atau profesi yang ia lakukan.

Membangun Personal Branding seseorang dipermudah dengan banyaknya media sosial yang bermunculan, salah satunya Media Sosial Instagram yang memiliki dampak besar pada kehidupan saat ini, dilihat dari banyak penggunanya yang mulai merasa sangat penting untuk menampilkan sosok dirinya agar dikenal orang lain. Berbagai karakter mereka pun ditunjukkan untuk popularitas dan eksistensinya dimata khalayak atau pengguna akun instagram lainnya. Instagram memungkinkan penggunanya untuk mengambil foto, mengedit, menerapkan filter digital, dan membagikan foto ke situs jejaring sosial seperti Facebook, Twitter, Foursquare, Tumblr, Flickr, Posterous dan jejaring sosial milik Instagram sendiri (Miles, 2014).

Pemilik akun Instagram yang memilki 
banyak followers akan dikenal dengan sebutan Selebgram/Selebritis Instagram. Selebritis Instagram adalah istilah untuk pengguna akun terkenal di situs jejaring sosial Instagram. Istilah itu merujuk pada kata Selebritis Instagram dimana perpaduan itu berarti orang yang terkenal layaknya selebriti di Instagram. Selebgram memiliki followers dan like yang real dengan jumlah yang banyak (Atmoko, dalam Ika Suryani Fitri, 2015).

Berdasarkan hasil pengamatan, seseorang dapat dikatakan sebagai Selebgram dilihat dari beberapa faktor diantaranya followers yang banyak, keindahan fotografi yang diunggah, kecantikan atau ketampanan dari pemilik akun tersebut, atau bahkan penampilan dalam memadu padankan pakaian. Salah satu Selebgram yang telah popoler pada saat ini yaitu selebgram berhijab. Perempuan berhijab saat ini semakin bisa menyesuaikan dirinya dengan tuntutan perkembangan zaman. Kebutuhan dan keinginan untuk beradaptasi dengan lingkungan sosial pun semakin tinggi. Oleh karena itu, beragam media sosial banyak diakses demi menunjang penampilan dan pergaulan mereka salah satunya melalui Instagram.

Setiap orang mempunyai keunikan masing-masing yang dimilikinya sejak lahir. Keunikan tersebut bisa dari nama, wajah, sifat, karakter, bakat dan masih banyak hal yang dapat membedakan satu orang dengan orang yang lainnya. Seiring dengan pertumbuhannya, keunikan seseorang dapat semakin berkembang kedalam keahlian-keahlian yang dimiliki dan didalaminya. Beberapa orang sadar bahwa keunikan yang dimiliki tak hanya semata-mata menjadi pembeda dengan orang yang lainnya, melainkan harus menjadi sebuah prestasi yang menonjol mengingat di zaman sekarang kompetisi antar individu semakin luas.

Dalam perkembangannya, model hijab wanita muslim Indonesia mengalami perubahan beriringan dengan munculnya komunitas jilbab yang membawa identitas Islam. Jilbab menjadi pakaian yang dapat disesuaikan dengan perkembangan fashion yang terkadang dalam penciptaannya luput dari aspek syari'at. fashion merupakan fenomena kultural yang digunakan kelompok untuk mengkonstruksi dan mengkomunikasikan identitasnya. Jilbab dapat digunakan menjadi simbol untuk merepresentasikan gaya hidup kelompok sosial melalui fashion.

Gaya hijab pada masa sekarang telah menjadi bagian penting dalam industri fashion di Indonesia, hal ini pula yang menjadi alasan mengapa peneliti lebih memilih Selebgram berhijab yang dijadikan subjek penelitian ini. Keberagaman gaya hijab mulai dari pakaian, berbagai bentuk scarf segi empat dan pashmina dengan motif yang beragam seperti motif flowers, animal print, tie dye, etnik, polkad ot serta motif lainnya yang semakin menarik dengan pemilihan warna yang segar dan tentunya tambahan aksesoris dengan berbagai 
macam bentuk yang cantik. Gaya hijab yang populer sekarang tentunya berbeda jauh dengan gaya hijab dahulu yang cenderung sederhana, monoton, tidak menarik, dan hanya banyak digunakan oleh muslimah yang berusia lanjut.

Pandangan masyarakat khususnya netizen terhadap selebgram menganggap bahwa seorang Selebgram adalah seorang yang memiliki ketenaran/kepoulerannya di Instagram, menyukai travelling, memiliki keahlian dan bakat, dapat memberikan inspirasi, karakter yang berbeda-beda, dan memiliki identitas diri dengan gaya hidup yang mewah karena ditunjang dengan penampilan/cara berpakaian, fasilitas yang ditampilkan, serta kualitas foto yang bagus pada setiap postingannya menandakan bahwa ia memiliki handphone atau kamera yang bagus dan berkualitas tinggi.

Setiap orang memiliki latar belakang masing-masing dan cara masing-masing dalam memenuhi kebutuhannya untuk dikenali banyak orang. Citra seorang selebgram berhijab akan dipandang positif oleh netizen karena mereka dapat menjadi panutan untuk menutupi auratnya. Selain dari itu, mereka juga telah Membentuk suatu Personal Branding dengan nilai jual personal yang sesuai dengan apa yang mereka miliki dan tonjolkan. Seperti bakat, karakter diri, identitas, ketenaran, dan tampilan fisik yang menunjang mereka memiliki personal branding masing-masing yang mencirikan diri mereka.

Dalam penelitian ini, peneliti tertarik untuk melakukan penelitian terkait dengan Instagram sebagai pembentuk Personal Branding Selebgram berhijab, dimana teori yang menjadi landasan dalam penelitian ini yaitu Personal Branding. Personal branding dapat mengatur persepsi seseorang terhadap orang lain, dengan menceritakan pengalaman kepada orang lain secara organik dan kebetulan sehingga orang lain berpikir persepsi itu dibangun sendiri (Montoya, 2002:27).

Personal branding juga dapat dikatakan sebagai proses dimana orang-orang dan karir mereka ditandai sebagai merek. Personal branding merupakan proses dimana seseorang dipandang sebagai sebuah brand (merek) oleh target market. Dapat disimpulkan bahwa personal branding adalah suatu proses membentuk persepsi masyarakat terhadap aspek-aspek yang dimiliki oleh seseorang, diantaranya adalah kepribadian, kemampuan, atau nilai-nilai, dan bagaimana stimulusstimulus ini menimbulkan persepsi positif dari masyarakat yang pada akhirnya dapat digunakan sebagai alat pemasaran (McNally \& Speak, 2002).

Hasil penelitian terdahulu mengenai strategi Personal Branding melalui Instagram (Agustinna, 2017) Penelitian ini menemukan bahwa pembentukan personal branding dalam media sosial instagram oleh Zahratuljannah memiliki keunikan. Zahratuljannah memiliki 
kompetensi diri yang dimilikinya, hal tersebut meliputi kepribadian, nilai-nilai yang dianut dan karakter yang dimilikinya. Selain itu konsistensi menjadi salah satu kunci utama pembentukan personal branding yang kuat. Tak hanya itu passion serta budaya yang ditanamkan sejak lahir menjadi hal yang dapat mempengaruhi suatu proses pembentukan personal branding. Selain itu konsistensi menjadi salah satu kunci utama pembentukan personal branding yang kuat. Bentuk personal branding yang dimiliki oleh Zahratul Jannah memiliki fokus yang beda. Zahratul Jannah yang memiliki passion dalam dunia fashion, membentuk personal branding di instagram sebagai seorang yang fashionable atau instagramers fashion.

Zahratul Jannah pun memiliki gaya khusus dari dirinya yaitu simple, dan casual. Instagram sebagai new media atau media baru dianggap memiliki suatu rencana kerja yang praktis untuk bersosialisasi serta membentuk suatu persepsi. Hal tersebutlah yang menjadi alasan Zahratul Jannah membangun personal branding yang dimiliki melalui media sosial Instagram. Tak hanya itu dengan berkomunikasi melalui media foto, video serta caption dapat membentuk suatu gambaran yang jelas akan personal branding yang dibangun oleh keduanya. Personal branding yang dibangun oleh Zahratul Jannah dalam media sosial instagram membawa banyak hal dalam kehidupannya. Zahratul Jannah mendapatkan banyak koneksi dengan orangorang yang memiliki interest yang sama, tak hanya itu kesempatan untuk bekerja sama dengan berbagai macam brand serta kegiatan promosi lainnya pernah ia lakukan. Terhitung brand besar seperti Hijup, The body Shop pernah bekerjasama dengan Zahratul Jannah. Kerjasama yang diterima oleh Zahratul Jannah memiliki keterikatan dengan personal branding yang telah dibentuk sebelumnya. Tak hanya itu, Zahratul Jannah pun telah menetapkan suatu standard diri untuk menjaga reputasi yang telah dimilikinya. (Agustinna, 2017)

Penelitian terdahulu lainnya yang terkait strategi personal branding yaitu Shopee Indonesia dalam memberikan informasi sebagai upaya membangun brand awareness dilakukan melalui kegiatan online seperti: melalui fitur aplikasi Shopee, informasi promo, tips berjualan dan berbelanja online, dan menggunakan social media ads. Pada tahap ini dapat dikatakan Shopee telah mencapai tingkat brand recognition, mampu mempengaruhi audiens untuk memilih menggunakan Shopee. (Anggraini, Perbawasari \& Budiana, 2018)

Peneliti melakukan penelitian dengan memilih objek yang diteliti yaitu Selebgram berhijab di kota Garut. Hal ini terbukti dari banyaknya Selebgram berhijab di Kota Garut diantaranya yaitu Rindhy Fajrin Oktavia dengan pemilik akun Instagram @ rindhyfos dengan jumlah 23.200 pengikut, Ashry Rizqky 
Rabani dengan akun Instagram @ashryrrabani dengan jumlah 139.000 pengikut, dan Irma Rismawati dengan akun Instagram @irmareismha dengan jumlah 120.000 pengikut. (Hasil Observasi di akun Instagram Selebgram berhijab diakses pada 07 Mei 2020 pukul 14:00)

Alasan dalam memilih selebgram berhijab dikarenakan perempuan berhijab lebih cenderung memiliki kepribadian tertutup. Namun pada kenyataanya mereka perempuan berhijab yang menjadi selebgram memiliki personal Branding yang kuat dan unik untuk menarik followers mereka. Seperti observasi yang telah peneliti lakukan pada masingmasing akun Instagram mereka, terlihat identitas diri dari konten yang mereka sajikan memiliki daya tarik dan nilai jual masingmasing dimulai dari kecantikan dan keanggunannya, keahlian serta karakter diri masing-masing yang unik. Keahlian para selebgram ini pun beragam ada yang memilki bakat dalam bernyanyi, presenter, dan ada yang pernah menjuarai sebagai Mojang Garut.

Sehingga Personal Branding yang mereka bentuk dalam sajian konten berhasil dalam

\section{METODOLOGI PENELITIAN}

Metodologi Penelitian merupakan ilmu yang mempelajari cara yang digunakan untuk menyelidiki masalah yang memerlukan pemecahan. Implisit dalam definisi metodologi adalah satu set prinsip-prinsip atau kriteria- menarik jumlah followers. Tawaran Endorse pun berdatangan, mulai dari kota Garut bahkan luar kota Garut.

Berdasarkan uraian yang telah dipaparkan, maka peneliti tertarik untuk melakukan penelitian dengan judul:

\section{"Instagram Sebagai Media Pembentuk}

Personal Branding (Studi Deskriptif Tentang Instagram Sebagai Media Pembentuk Personal Branding Selebgram Berhijab Di Kota Garut Dalam Menarik Followers)"

Adapun tujuan penelitian ini diantaranya:

1. Untuk menganalisis Personal Branding yang dibentuk Selebgram Berhijab melalui Gaya/Style dalam menarik followers.

2. Untuk menganalisis Personal Branding yang dibentuk Selebgram Berhijab melalui kompentensi/kemampuan dalam menarik followers.

3. Untuk menganalisis Personal Branding yang dibentuk Selebgram Berhijab sebagai standar diri di Instagram.

kriteria yang dengannya para metodologis dapat menilai kebenaran dari prosedurprosedur penelitian. Metodologi penelitian menuntun mengarahkan pelaksanaan penelitian agar hasilnya sesuai dengan realitas. Jadi, 
metodologi merupakan ilmu metode dan pengetahuan tentang cara untuk melakukan penelitian pada asasnya sama dengan metodologi penelitian. Metodologi penelitian adalah ilmu tentang metode penelitian (science of research methods) (Nurhadi \& Din, 2012: 41).

Penelitian ini menggunakan metode deskriptif kualitatif. Penelitian deskriptif merupakan situasi atau peristiwa. Peneliti tidak mencari atau menjelaskan hubungan, serta tidak menguji hipotesis. Penelitian deskriptif yaitu mengumpulkan data berdasarkan faktorfaktor yang menjadi pendukung terhadap objek penelitian, kemudian menganalisis faktorfaktor tersebut untuk dicari peranannya (Arikunto, 2010). Metode deskriptif adalah metode penelitian yang berusaha menggambarkan dan menginterpretasi objek sesuai apa adanya (Sukardi, 2009). Metode deskriptif digunakan untuk menggambarkan rumusan masalah.

Pendekatan kualitatif adalah suatu proses penelitian dan pemahaman yang berdasarkan pada metodologi yang menyelidiki suatu fenomena sosial dan masalah manusia. Pada pendekatan ini, peneliti membuat suatu gambaran kompleks, meneliti kata-kata, laporan terinci dari pandangan responden, dan melakukan studi pada situasi yang dialami
(Ardial, 2014)

Teknik pemilihan informan menggunakan teknik purposive sampling. Teknik ini dilakukan dengan cara peneliti sudah menentukan jumlah informan secara purposive sesuai tujuan yang ingin diperoleh. Polkinghorne merekomendasikan bahwa riset peneliti mewawancarai 5 sampai 25 informan yang memiliki semua pengalam di dalam sebuah kejadian (Moleong, 2010). Pada penelitian ini peneliti menetapkan informan berjumlah lima orang. Strategi ini menghendaki informan dipilih berdasarkan pertimbangan peneliti dengan tujuan tertentu.

Subjek peneliti ini adalah Selebgram berhijab yang ada di kota Garut dimana Peneliti akan mewawancarai 5 orang Selebgram berhijab. Adapun alasan peneliti, menilai bahwa ke 5 informan ini diangggap memiliki kemampuan dan juga memiliki interpretasi yang baik dalam menjawab setiap pertanyaan.

Mekanisme penentuan informan pada penelitian ini di bagi menjadi tiga tahap diantaranya:

1. Melakukan observasi dengan cara mengikuti beberapa akun Instagram selebgram Berhijab di Kota Garut.

2. Menyeleksi akun instagram selebgram berhijab yang memiliki personal branding dan memiliki banyak followers minimal 5000. 
3. Melakukan pemilihan informan dari data yang telah di peroleh.

Peneliti menentukan kriteria dasar orang-orang yang dijadikan informan Adapun yang menjadi Kriteria Informan selebgram berhijab di kota Garut sebagai berikut:

1. Selebgram Berhijab dengan jumlah followers dan like yang real.

2. Berdomisili di Garut.

3. Usia 20-30 Tahun.

4. Aktif dalam akun Instagramnya.

5. Pernah melakukan endorsement minimal 5 kali.

6. Memiliki jumlah pengikut minimal 5.000 followers di akun Instagram nya.

7. Memiliki personal branding yang sering diperlihatkannya melalui kompetensi/kemampuan serta cirikhas style/gaya yang dimiiliki.

8. Bersedia mengikuti proses penelitian hingga selesai.

Pengumpulan data adalah teknik atau cara-cara yang dapat dipergunakan periset untuk mengumpulkan data. Setelah penelitian melakukan berbagai kegiatan pengumpulan data di lapangan dari para sumber informasi, data di organisasikan dan dimasukan ke dalam penyimpangan data untuk memudahkan proses lebih lanjut. Pencatatan data dilapangan dilakukan dengan membuat catatan harian dalam sebuah buku, laptop atau smartphone yang bisa dikombinasikan dengan data-data pendukung berupa data-data foto dan laian-lain
(Kriyantono, 2009).

Pengumpulan data pada penelitian ini adalah wawancara mendalam. Setelah peneliti melakukan berbagai kegiatan pengumpulan data dilapangan dari para sumber informasi, data diorganisasikan dan dimasukan ke dalam penyimpanan data untuk memudahkan ke proses lebih lanjut. Pencatatan berdasarkan data dari informan dalam sebuah buku catatan, dan di kombinasikan dengan data-data pendukung berupa data-data dokumentasi seperti foto.

Analisis data adalah proses mengorganisasikan dan mengurutkan data kedalam pola, kategori dan satuan uraian dasar sehingga tema dapat ditemukan dan dihipotesis kerja dapat dirumuskan seperti disarankan oleh data (Ardiyanto, 2011). Peneliti melalukan proses pemilahan untuk menyederhanakan data yang bersifat abstrak dan "kasar". Reduksi data diawali dengan memberikan kode pada setiap data yang dikumpulkan. Dengan adanya pemberikan kode ini, data yang dikumpulkan akan lebih mudah untuk direduksi. Peneliti juga mempelajari data-data secara lebih mendalam dan berusaha untuk menemukan makna-makna untuk masing-masing individu dan kemudian mengelompokannya berdasarkan kategori yang tepat atau sesuai mengenai Personal Branding Selebgram Berhijab di Kota Garut.

Tahap penyajian data ini merupakan tahap lanjut dari reduksi, yaitu mulai menyusun 
data-d ata menurut alur cerita tertentu. Beberapa data yang dinilai merusak suatu alur cerita dipertimbangkan untuk tidak disajikan. Dengan teknik menyajikan data seperti ini, diharapkan gambaran mengenai temuan penelitian dapat diketahui secara bertahap.

Selanjutnya tahap interpretasi dan penarikan Kesimpulan dimana peneliti berupaya melakukan interpretasi terhadap temuan-temuan penelitian. Interpretasi didasarkan pada hasil-hasil kajian literature yang telah dilakukan atau dikaitkan dengan wacana-wacana yang terkait dengan temuan penelitian. Hasil Interpretasi ini mengarahkan peneliti pada kesimpulan, yang menjawab pertanyaan yang telah dinyatakan pada awal penelitian ini. Kesimpulan yang disusun diharapkan dapat ditarik lebih lanjut pada pernyataan-pernyataan yang bernilai lebih umum, menjadi tesis sebagai hasil penelitian yang dilakukan.

Dalam penelitian ini, teknik pengumpulan data dilakukan dengan cara wawancara mendalam dan observasi langsung kepada setiap informan yang ditentukan dengan pengamatan yang dilakukan dimana peneliti terlibat langsung. Informan yang dipilih sesuai dengan pengetahuan mereka terhadap personal Branding khususnya bagi seorang Selebgram.

Proses triangulasi sumber juga dilakukan oleh

peneliti untuk mendapat data yang valid dalam penelitian ini.
Adapun profil informan dalam penelitian ini sebagai berikut:

Tabel 1. Profil Informan

\begin{tabular}{|c|l|l|c|l|}
\hline No & \multicolumn{1}{|c|}{$\begin{array}{c}\text { Nama } \\
\text { Informan }\end{array}$} & Id Instagram & Umur & Profesi \\
\hline 1 & Ajeng Sopha H & @ajengsopha_ & 20 & Model \\
\hline 2 & Rindhy Fajrin & @rindhyfos & 23 & $\begin{array}{l}\text { Model dan } \\
\text { Entrepreneur }\end{array}$ \\
\hline 3 & $\begin{array}{l}\text { Neng Amelia } \\
\text { N }\end{array}$ & @nengamelianh & 23 & $\begin{array}{l}\text { Entrepreneur } \\
\text { dan MC }\end{array}$ \\
\hline 4 & $\begin{array}{l}\text { Irma } \\
\text { Rismawati }\end{array}$ & @irmareismha & 25 & $\begin{array}{l}\text { Model dan } \\
\text { Entrepreneur }\end{array}$ \\
\hline 5 & $\begin{array}{l}\text { Ashry R } \\
\text { Rabani }\end{array}$ & @ashryrrabani & 23 & $\begin{array}{l}\text { Influencer } \\
\text { dan } \\
\text { Entrepreneur }\end{array}$ \\
\hline
\end{tabular}

Sumber: Hasil penelitian

\section{HASIL DAN PEMBAHASAN}

\section{Personal Branding Selebgram Berhijab} Melalui Gaya/Style dari segi ciri khas

\begin{tabular}{|c|c|c|c|c|}
\hline $\begin{array}{c}\text { Informan I } \\
\text { Ajeng }\end{array}$ & $\begin{array}{c}\text { Informan } \\
\text { II } \\
\text { Irma }\end{array}$ & $\begin{array}{c}\text { Informan } \\
\text { III } \\
\text { Rindhy }\end{array}$ & $\begin{array}{c}\text { Informan } \\
\text { IV } \\
\text { Neng } \\
\text { Amelia }\end{array}$ & $\begin{array}{c}\text { Informan } \\
\text { V } \\
\text { Ashry }\end{array}$ \\
\hline $\begin{array}{l}\text { Casual } \\
\text { namun tetap } \\
\text { fashionable. } \\
\text { Gaya hijab } \\
\text { pashmina } \\
\text { yang } \\
\text { terkesan } \\
\text { sederhana } \\
\text { dan simple. }\end{array}$ & $\begin{array}{l}\text { Casual } \\
\text { dengan } \\
\text { gaya } \\
\text { hijab } \\
\text { pashmina. }\end{array}$ & $\begin{array}{l}\text { Gaya } \\
\text { hijab } \\
\text { sehari- } \\
\text { hari/daily. }\end{array}$ & $\begin{array}{l}\text { Gaya hijab } \\
\text { yang } \\
\text { sedang } \\
\text { disukainya. } \\
\text { Terutama } \\
\text { yang } \\
\text { sesuai } \\
\text { dengan } \\
\text { bentuk } \\
\text { wajah. }\end{array}$ & $\begin{array}{l}\text { Gaya } \\
\text { hijab } \\
\text { fleksibel } \\
\text { serta tidak } \\
\text { menyukai } \\
\text { hijab } \\
\text { dengan } \\
\text { warna } \\
\text { mencolok. }\end{array}$ \\
\hline
\end{tabular}

Karakteristik personal branding salah satunya adalah ciri khas yang dimiliki seseorang. Menurut McNally \& Speak (2012, dalam Imawati, 2016: 176) Personal branding yang tidak hanya berbeda, tetapi merupakan cerminan dari ide-ide dan nilai-nilai dalam diri yang membentuk kekhasan seseorang. dengan Style/gaya selebgram yang mereka perlihatkan dapat menentukan ciri khas diri mereka 
masing-masing. Dari gaya/style masing-masing selebgram tersebut terdapat tahap perencanaan tertentu untuk mengaktualisasikan diri mereka ketika mengambil foto style nya.

Pendapat narasumber sebagai owner zoya mengungkapkan bahwa selebgramselebgram berhijab yang ditentukan untuk foto produk zoya lebih kepada pemakaian foto OOTD (outfit of the day) sehingga pada foto tersebut dapat memperlihatkan ciri khas dari style yang mereka pakai dengan menggunakan brand zoya yang sudah dikenal. Hal tersebut menegaskan bahwa Selebgram yang merupakan orang-orang terkenal seperti mereka bisa memakai produk zoya sehingga orang-orang dapat mengikuti apa yang mereka pakai.

Personal Branding Selebgram Berhijab Melalui Gaya/Style dari segi menulis caption

\begin{tabular}{|l|l|l|l|l|l|}
\hline & $\begin{array}{c}\text { Informan } \\
\text { I } \\
\text { Ajeng }\end{array}$ & $\begin{array}{l}\text { Informan } \\
\text { II } \\
\text { Irma }\end{array}$ & $\begin{array}{c}\text { Informan } \\
\text { III } \\
\text { Rindhy }\end{array}$ & $\begin{array}{c}\text { Informan } \\
\text { IV } \\
\text { Neng } \\
\text { Amelia }\end{array}$ & $\begin{array}{c}\text { Informan } \\
\text { V } \\
\text { Ashry }\end{array}$ \\
\hline $\begin{array}{l}\text { Czption } \\
\text { Endorsement }\end{array}$ & $\begin{array}{l}\text { Berdasarkan } \\
\text { konten yang } \\
\text { dimuat. }\end{array}$ & $\begin{array}{l}\text { Sesuai } \\
\text { dengan } \\
\text { kualitas } \\
\text { produk. }\end{array}$ & $\begin{array}{l}\text { Berdasarkan } \\
\text { konten yang } \\
\text { dimuat. }\end{array}$ & $\begin{array}{l}\text { Berdasarkan } \\
\text { konten yang } \\
\text { dimuat. }\end{array}$ & $\begin{array}{l}\text { Berdasarkan } \\
\text { konten yang } \\
\text { dimuat. }\end{array}$ \\
\hline $\begin{array}{l}\text { Caption } \\
\text { sebagai } \\
\text { pengetahuan }\end{array}$ & $\begin{array}{l}\text { Memberikan } \\
\text { pengetahuan } \\
\text { mengenai } \\
\text { konten, }\end{array}$ & & & $\begin{array}{l}\text { Memberikan } \\
\text { pengetahuan } \\
\text { mengenai } \\
\text { konten, }\end{array}$ & \\
\hline $\begin{array}{l}\text { Caption } \\
\text { sebagai } \\
\text { karakter } \\
\text { diri }\end{array}$ & $\begin{array}{l}\text { Caption } \\
\text { yang } \\
\text { memotivasi, } \\
\text { menghibur } \\
\text { disesuaikan } \\
\text { dengan foto } \\
\text { yang di- } \\
\text { posting. }\end{array}$ & $\begin{array}{l}\text { Caption } \\
\text { yang } \\
\text { simple. }\end{array}$ & $\begin{array}{l}\text { Caption } \\
\text { yang simple. }\end{array}$ & & \\
& & & & \\
& & & & \\
\hline
\end{tabular}

Gaya/style selebgram juga dapat terlihat dari cara mereka menulis caption. Caption merupakan suatu deskripsi dari foto/video yang akan diposting agar orangorang yang melihat foto/video tersebut mengerti apa maksud dari foto/video tertentu termasuk caption yang besifat untuk mempengaruhi khalayak instagram. Gaya disini merupakan cara kita berhubungan dengan orang lain dalam hal ini cara selebgram berhubungan dengan khalayak instagram dimana mereka sering mempengaruhi dan memperlihatkan karakteristik dirinya melalui tulisan caption.

Menurut Montoya (2008, dalam imawati, 2016:178) Kepribadian (The Law of Personality) dalam Personal branding yang baik menggambarkan kepribadian individu dalam segala aspek, artinya bukan hanya kelebihan atau kesempurnaan, tetapi juga ketidaksempurnaan individu tersebut karena orang lain justru menyukai sosok yang apa adanya, yaitu yang memiliki kelemahan seperti selayaknya seorang manusia. Konsep ini berseberangan dengan Konsep Kepemimpinan yang menekankan individu untuk berkepribadian sangat baik.

Dengan personal branding, individu akan menjadi seseorang yang pertama terpikirkan ketika orang lain mencari atau membutuhkan potensi, kualitas, atau nilai-nilai tertentu yang ada dalam diri individu tersebut (Hood, 2006 dalam Imawati, 2016: 176). Pernyataan tersebut sejalan dengan pemikiran peneliti bahwa dari apa yang selebgram tampilkan melalui style-nya akan memberikan nilai-nilai bagi orang lain ketika orang lain mencari atau membutuhkan suatu nilai yang dimiliki selebgram berhijab tersebut misalnya 
ketika followers-nya sedang mencari style apa yang menjadi ciri khas dan karakter mereka masing-masing sebagai kebutuhan followersnya.

\section{Personal Branding Yang Dibentuk Selebgram}

Berhijab Melalui Kompentensi/Kemampuan

\begin{tabular}{|c|c|c|c|c|c|c|}
\hline & & $\begin{array}{c}\text { Informan } \\
\text { I } \\
\text { Ajeng }\end{array}$ & $\begin{array}{c}\text { Informan } \\
\text { II } \\
\text { Irma }\end{array}$ & $\begin{array}{l}\text { Informan } \\
\text { III } \\
\text { Rindhy }\end{array}$ & $\begin{array}{c}\text { Informan } \\
\text { IV } \\
\\
\text { Neng } \\
\text { Amelia }\end{array}$ & $\begin{array}{c}\text { Informan } \\
\mathbf{V} \\
\text { Ashry }\end{array}$ \\
\hline \multirow[t]{5}{*}{ Kompetensi } & $\begin{array}{l}\text { Sebagai } \\
\text { duta } \\
\text { pariwisata } \\
\text { dan seni } \\
\text { budaya }\end{array}$ & $\begin{array}{l}\text { Menari. } \\
\text { dan } \\
\text { menulis. } \\
\text { puisis }\end{array}$ & & & & $\begin{array}{l}\text { Menari } \\
\text { tradisional. }\end{array}$ \\
\hline & $\begin{array}{l}\text { Motor } \\
\text { Cross. }\end{array}$ & & & $\begin{array}{l}\text { Balapan } \\
\text { motor dan } \\
\text { karate. }\end{array}$ & & \\
\hline & $\begin{array}{l}\text { Publikk } \\
\text { Speaking }\end{array}$ & & & & $\begin{array}{l}\text { Pemborala } \\
\text { acara. }\end{array}$ & $\begin{array}{l}\text { Corporate } \\
\text { Publik } \\
\text { Speakers }\end{array}$ \\
\hline & $\begin{array}{l}\text { Fashion } \\
\text { Influencer }\end{array}$ & $\begin{array}{l}\text { Tutorial } \\
\text { make-up } \\
\text { dan hijab. }\end{array}$ & $\begin{array}{l}\text { Tutorial } \\
\text { Hijab. }\end{array}$ & $\begin{array}{l}\text { Fashion } \\
\text { untuk } \\
\text { travelling. }\end{array}$ & $\begin{array}{l}\text { Tutorial } \\
\text { make-up } \\
\text { dan hijab. }\end{array}$ & $\begin{array}{l}\text { Inspirasi } \\
\text { fashion } \\
\text { dan filter } \\
\text { Instagram. }\end{array}$ \\
\hline & $\begin{array}{l}\text { Kompetensi } \\
\text { Bissuis }\end{array}$ & & $\begin{array}{l}\text { Bisnis } \\
\text { travel. }\end{array}$ & $\begin{array}{l}\text { Bisnis } \\
\text { Kaos. }\end{array}$ & $\begin{array}{l}\text { Bisnis } \\
\text { Fashion. }\end{array}$ & $\begin{array}{l}\text { Bisnis } \\
\text { Fashion } \\
\text { Muslim. }\end{array}$ \\
\hline
\end{tabular}

personal branding, kita harus memiliki suatu kemampuan khusus atau kompetensi dalam satu bidang tertentu yang dikuasai. Seseorang dapat membentuk sebuah personal branding melalui sebuah polesan dan metode komunikasi yang disusun dengan baik. Personal Brand adalah sebuah gambaran mengenai apa yang masyarakat pikirkan tentang seseorang. Hal tersebut mencerminkan nilai-nilai, kepribadian, keahlian dan kualitas yang membuat seseorang berbeda dengan yang lainnya (McNally \& Speak, 2002: 26 dalam Imawati, 2016).

Berdasarkan pengamatan peneliti pada masing-masing akun instagram informan, terlihat bahwa terdapat kompetensi yang masing-masing mereka miliki pada bidang tertentu. Sehingga persepsi-persepsi dari khalayak instagram pun bermunculan bahwa ternyata selain memiliki paras yang cantik, selebgram-selebgram berhijab yang ada di kota Garut ini memiliki nilai tambah dirinya dari kompetensi yang mereka miliki. Dari personal branding yang mereka miliki juga dapat memperkuat pada branding produk bisnisnya karena mereka telah membranding diri melalui instagram yang akan menciptakan berbagai persepsi dari khalayak, sehingga akan berpengaruh pula pada branding produk yang mereka miliki.

Data penelitian dari kelima informan memang relevan dengan pernyataan narasumber. Personal branding yang dimiliki selebgram berhijab juga berpengaruh pada suatu produk tertentu. Menurut hasil triangulasi dengan narasumber yang merupakan owner dari Zoya Garut mengungkapkan bahwa terpilihnya mereka sebagai model endorse atau catalog juga berdasarkan pemilihan dari pusat yaitu pemilihan face of zoya seperti talent hunter sehingga dipilih lah orang-orang garut dan model yang berprestasi mewakili nasional dari seluruh daerah di indonesia dan selebgram-selebgram tersebut yang terpilih karena kebanyakan dari mereka adalah Mojang Kabupaten Garut serta pernah mengikuti kejuaraan dan prestasi lainnya.

Untuk mengecek keabsahan data dari informan, maka peneliti melakukan triangulasi sumber dimana hasil triangulasi sumber dengan Dr. Mulyaningsih yang menyatakan bahwa dengan memanfaatkan media instagram 
tentunya tidak hanya memperlihatkan secara personal saja, akan tetapi perlu untuk memperlihatkan apa potensi, kompetensi yang dimiliki selebgram tersebut. Instagram sebagai media para selebgram untuk memperlihatkan dan menyalurkan potensi yang mereka miliki. Jadi dengan perkembangan teknologi pada saat ini dapat memudahkan, lebih luas jangkauan, dan informasi yang disampaikan secara kuantitas kepada masyarakat mengenai personal branding yang dimiliki. Relevan dengan jawaban narasumber bahwa dengan memperlihatkan dan membangun personal branding mengenai potensi apa yang ditonjolkan selebgram, tentunya akan dibutuhkan oleh suatu komuntas atau perusahaan tertentu, terbukti dari salah satu informan yang dibutuhkan oleh suatu perusahaan untuk aktivitas endorse, kampanye, serta menjadi speakers pada acara talkshow suatu corporate.

Menurut Montoya (2008, dalam imawati, 2016:178) terdapat konsep utama personal branding salah satunya adalah Kenampakan (The Law of Visibility) di mana untuk menjadi sukses, personal brand harus terlihat secara konsisten atau terus-menerus hingga personal branding orang tersebut dikenal. Hal ini karena kenampakan lebih penting dibandingkan keahlian. Ada banyak orang dengan keahlian yang sama, karenanya individu harus membuat dirinya lebih nampak atau terlihat dibanding yang lain.
Dengan melalui media sosial, mereka dapat memperlihatkan apa yang aneh dari yang mereka miliki dan juga untuk memudahkan masyarakat atau komunitas tertentu untuk mencari kebutuhan-kebutuhan berbagai jenis kompetensi yang ada didalam diri seseorang khususnya selebgram. maka dari itu seorang selebgram harus memiliki self branding-nya mengenai apa yang ingin ditampilkan dirinya apakah kompetensi, pekerjaan, ataupun usahanya.

Untuk memperoleh personal brand yang baik pertama-tama yang dibutuhkan adalah "produk" yang baik. Produk di sini dapat berupa keahlian, attitude, penampilan, cara bicara dan tentu saja yang tidak kalah penting adalah reputasi. Setelah itu, diperlukan cara mengkomunikasikan reputasi atau produk tersebut. Dalam hal komunikasi ini terdapat banyak caranya seperti misalnya menulis artikel, menjadi pembicara, mengajar, terlibat dalam organisasi profesi, memiliki online networking atau blog dan sebagainya. Tentu saja kegiatan tersebut perlu dikaitkan dengan talenta dan kesukaan seseorang. Seseorang yang lebih senang menulis akan lebih memilih menulis artikel dan yang senang sebagai pembicara akan memilih menjadi pembicara (Catur, 2011 dalam Syaifudd in, 2013:122).

Menurut Amalia Maulana (dalam Tamimy, 2017 :4) ada tiga hal yang dibutuhkan agar branding berhasil dilakukan, diantaranya clarity (kejelasan), consistency (tetap pada 
image-nya), dan constancy (selalu ada dimana pun dibutuhkan). Seperti diketahui, ruang lingkup media sosial tidak terpaku pada orangorang terdekat saja, tetapi mampu menjangkau jaringan yang lebiih luas. Media sosial instagram juga membawa kekuatan tersendiri dalam memperoleh referensi potensial terhadap orang-orang berpengaruh diseluruh dunia. Sehingga sejalan dengan pernyataan dari narasumber yaitu Dr. Mulyaningsih, dengan apa yang selebgram perlihatkan melalui kompetensi yang dimilikinya dapat menjadi referensi atau berbagai kebutuhan jenis kompetensi bagi individu (followers) maupun komunitas tertentu karena mereka orang-orang yang berpengaruh dalam dunia fashion melalui style yang digunakannya.

\section{Personal Branding Yang Dibentuk Selebgram Berhijab Sebagai Standard Diri Di Instagram}

Standar personal branding sangat mempengaruhi cara orang lain memandang diri kita. Standar akan menetapkan dan memberikan makna terhadap kekuatan personal branding. Namun kuncinya adalah kita sendiri yang menetapkan standar, kita sendiri yang harus melakukan.Terkadang kita menetapkan standar yang terlalu tinggi dan terlanjur mengatakan pada orang lain bahwa kita mampu melakukan suatu hal dengan cepat dan dapat memperoleh hasil yang baik (agar kompetensi dan gaya personal branding kita kelihatan menarik di benak semua orang). Namun yang terjadi adalah sebaliknya, terkadang kita gagal untuk mencapai standar yang kita tetapkan sendiri Jadi dengan menggabungkan ketiga faktor tersebut, yaitu kompetensi, style dan standart, kita dapat mulai terus membangun dan mengembangkan reputasi dalam bidang khusus yang di pilih dan Proses membangun reputasi adalah proses seumur hidup. Kita berharap semakin bertambah usia kita, semakin kuat "brand" kita di masyarakat (McNally \& Speak, 2002: 26).

Dr. Mulyaningsih memandang bahwa selebgram mendapat sorotan tersendiri terlihat dari siapa mereka, seberapa banyak orangorang melihat mereka, seberapa banyak orangorang yang menyukai atau tidak menyukai selebgram. Hal tersebut menjadi suatu evaluasi bagi selebgram berhijab, karena jika sudah memasuki media sosial terlebih instagram pandangan netizen tentunya akan berbeda-beda terhadap selebgram berhijab. Sehingga selebgram harus mampu dan siap menerima berbagai komentar atau tanggapan baik itu positif maupun negatif. bahwa cara seseorang memperlihatkan dirinya harus mengedepankan etika dan sopan santun, karena etika sangat melekat dalam instagram seseorang apalagi perempuan yang mengenakan hijab yang seharusnya tahu batasan. Kehidupan yang bersifat pribadi secara detail dan prinsipil pun tidak boleh diekspos dan diketahui netizen karena mereka adalah seorang selebgram yaitu public figure yang mendapat sorotan orang 
banyak sehingga harus memiliki etika ramburambu publik.

Branding di media sosial adalah suatu upaya guna menampilkan informasi, pesan, dan kesan melalui aktivitas yang dilakukan, seperti menampilkan profil, meng-update status, mengunggah foto, berbagi informasi dan pandangan berupa opini, serta memberikan feedback seperti komentar, dan ikon like. Masih banyak pengertian branding yang dapat kita pahami dalam kehidupan sehari-hari. Namun, secara garis besar, branding dapat diartikan sebagai sebuah upaya menyampaikan informasi dan pandangan terhadap orang lain, berdasarkan apa yang diinginkan oleh pemilik brand itu sendiri.

Fungsi personal branding adalah sebagai usaha untuk memberikan perhatian kepada orang lain atas kemampuan, keunikan, spesialisasi, dan citra diri berbeda yang dimiliki, bahkan lebih unggul dibandingkan orang lain. Tujuan personal branding untuk membangun citra dari apa yang ingin ditampilkan seseorang agar mampu memikat dan membangun kepercayaan terhadap orang lain (Tamimy, 2017:4).

Dari standar diri yang sudah di tetapkan oleh masing-masing selebgram dinilai sebagai evaluasi dirinya, karena ketika seseorang sudah memasuki media sosial instagram harus siap untuk menerima berbagai komentar dari netizen mengenai gaya/style, serta kompetensi mereka sebagai standar dirinya di instagram. Ada harapan tertentu dari selebgram dalam membangun personal branding melalui style/gaya, kompetensi/kemampuan sebagai standar dirinya untuk menarik followers dan juga peng-endorse akan melihat jumlah followers selebgram berhijab tersebut. Adapun hasil triangulasi sumber dari owner zoya Garut memilih selebgram-selebgram tertentu untuk menjadi model catalog produk atau endorse karena kebetulan mengenali dan mereka merupakan orang-orang yg terkenal di Garut terlihat dari banyaknya followers pada masingmasing akun yang tentunya dapat menarik konsumen zoya jika mereka pakai produk zoya. Orang-orang terkenal seperti mereka bisa memakai zoya sehingga orang-orang dapat mengikuti apa yang dikenakan mereka. Seseorang yang memiliki banyak followers khususnya selebgram berhijab di Garut akan menjadi sorotan netizen- nya. Beliau menggunakan peluang tersebut untuk produkproduk zoya agar lebih banyak diminati dan dikenal.

\section{PENUTUP}

Personal branding yang dibentuk berdasarkan tiga dimensi utama pembentukan personal branding (McNally \& Speak, 2002) yang mereka perlihatkan pada masing-masing akun instagram diantaranya pertama, Gaya/style mengandung suatu emosi yang kuat ketika berhubungan dengan orang lain. Adapun gaya yang diperlihatkan selebgram berhijab ketika mereka mem-posting-nya dalam bentuk 
foto style maupun dalam cara mereka menulis caption akan berbeda-beda. Gaya/style seseorang dalam berpakaian merupakan komunikasi non-verbal yang dapat memberikan penilaian dari orang lain mengenai siapa dirinya, kepribadiannya, apa keunikannya yang dapat membedakannya dengan yang lain. Begitu pun juga dengan selebgram berhijab yang merupakan objek dalam penelitian ini, mereka membentuk personal branding dengan melalui style/gaya yang mereka perlihatkan di instagram dengan ciri khas masing-masing yang berbeda. Selain ciri khas yang menjadikannya unik ada pula tahapan-tahapan dalam perencanaan untuk mengaktualisasikan dirinya melalui foto style. Gaya/style selebgram juga dapat terlihat dari cara mereka menulis caption. Caption merupakan suatu deskripsi dari foto/video yang akan diposting agar orang-orang yang melihat foto/video tersebut mengerti apa maksud dari foto/video tertentu termasuk caption yang besifat untuk mempengaruhi khalayak instagram. Gaya dan cara selebgram berhubungan dengan khalayak instagram terlihat dimana caption yang ditulis dapat mempengaruhi followers akan suatu produk yang di endorse, caption sebagai pengetahuan untuk followers serta caption yang dapat memperlihatkan karakter diri.

Kedua, memiliki suatu kemampuan khusus atau kompetensi dalam satu bidang tertentu yang dikuasa selebgram dapat membentuk personal branding melalui sebuah polesan dan metode komunikasi yang disusun dengan baik. Dengan masing-masing kompetensi yang dimiliki selebgram berhijab yang diperlihatkan di akun instagram-nya dapat menarik individu/followers, komunitas tertentu, online shop dan perusahaan tertentu yang membutuhkan berbagai kompetensi yang dimiliki selebgram. Kompetensi/kemampuan yang dimiliki selebgram dapat menambah branding dirinya dengan berbagai potensi yang dimiliki diantaranya kompetensi public speaking, kompetensi sebagai duta pariwisata dan seni budaya, fashion influencer, content creator, kompetensi olah raga karate dan motor cross serta kompetensi dalam bisnisnya dimana mereka memiliki brand sendiri dalam produk bisnisnya. Dengan melalui instagram, mereka dapat memperlihatkan apa yang aneh dari yang mereka miliki dan juga untuk memudahkan masyarakat atau komunitas tertentu untuk mencari kebutuhan-kebutuhan berbagai jenis kompetensi yang ada didalam diri seseorang khususnya selebgram.

Ketiga, standar diri yang ditetapkan selebgram berhijab melalui gaya/style serta kompetensi/kemampuan yang diperlihatkan di instagram-nya berbeda-beda. Personal branding yang dibentuk tidak selamanya akan melahirkan persepsi yang baik. Dari standar diri yang sudah di tetapkan oleh masingmasing selebgram dinilai sebagai evaluasi dirinya, karena ketika seseorang sudah memasuki media sosial Instagram. harus siap 
untuk menerima berbagai komentar dari netizen baik itu komentar bersifat positif maupun negative mengenai gaya/style, serta kompetensi mereka sebagai standar diri dan evaluasi dirinya di instagram. Ada harapan tertentu bagi selebgram dalam membangun personal branding melalui style/gaya, kompetensi/kemampuan sebagai standar

\section{DAFTAR PUSTAKA}

Agustinna, Kartika. (2017). Analisis Strategi Personal Branding Melalui Media Sosial Instagram. Universitas Telkom. Bandung.

Anggraini, Chindy Ayu; Perbawasari, Susie; Budiana, Heru Ryanto. (2018). Cyberbranding sebagai upaya membangun Brand Awareness Shopee Indonesia. Commed: Jurnal Komunikasi dan Media, [S.1.], v. 2, n. 2, p. 72-86, apr. 2018. ISSN 26156725.

Ardial, H. (2014). Paradigma Dan Model Penelitian Komunikasi. Jakarta: Bumi Aksara.

Ardiyanto, Elvinaro. (2011). Metode Penelitian Untuk Public Relations Kuantitatif Dan Kualitatif. $\quad$ Bandung: $\quad$ Simbiosi Rekatama Media.

\begin{tabular}{lr} 
& Metode \\
\hline Penelitian Untuk Public & Relations \\
Kuantitatif Dan Kualitatif. & Bandung: \\
Simbiosi Rekatama Media. &
\end{tabular}

Arikunto, Suharsimin. (2010). Prosedur Penelitian Suatu Pendekatan Praktik. Jakarta: Rineka Cipta.

Fitri, Ika Surya. (2015). Strategi Promosi Penjualan Produk Pada Media Sosial Instagram. Fakultas Ilmu Sosial Dan Ilmu Politik Jurusan Ilmu Komunikasi Universitas Lampung. Bandar Lampung.

http://dosen.stainwatampone.ac.id/download/H IJAB\%20JILBAB\%20MENURUT\%20 dirinya untuk menarik followers dan juga endorse. Jadi dengan menggabungkan ketiga faktor tersebut, yaitu kompetensi, style dan standart, selebgram dapat mulai terus membangun dan mengembangkan reputasi dalam bidang yang dikuasainya khusus yang di pilih dan proses membangun personal branding.

HUKUM\%20FIKIH.pdf [11 Maret $]$ Pada pukul 11:17.

http://repository.telkomuniversity.ac.id/pustaka /123913/strategi-personal-brandingselebgram-melalui-media-sosialinstagram.html [11 Maret] Pada pukul 14:17.

https://tekno.kompas.com/read/2016/03/08/110 30047/Rahasia.Jadi.Selebgram.Cara.Ra up.Untung.Lewat.Instagram. [08 Maret 2018] pada pukul 9:51.

Imawati, Amanda V. (2016). Analisis Personal Branding Fashion Blogger Diana Rikasari. Universitas Presiden. Bekasi.

Iriantara, Yosal. (2005). Media Relations: Konsep, Pendekatan, Dan Praktik. Bandung: Simbiosa Rekatama Media.

Kriyantono, R. (2008). Teknik Praktek Riset Komunikasi. Jakarta: Kencana Prenada Media Group.

Mcnally, D.,\& Speak, K. D. (2002) Be Your Own Brand: Resep Jitu Meraih Personal Branding Yang Unggul. Gramedia

Miles, Jason G. Miles. 2014. Instagram Power. Build Your Brand And Reach More Customers With The Power Of Pictures. The United States Of America.

Moleong, Lexy J. (2010). Metodologi Penelitian Kualitatif. Bandung: Remaja Rosda Karya.

Nurhadi, Zikri Fachrul Dan Makbul A.H Din. (2012). Metodologi Penelitian Kualitatif: Teori Dan Paradigma. Bandung: Alfabeta.

Sukardi. (2009). Metode Pendidikan Dan 
Pembangunan. Jakarta: Kencana Prenad a Media Group.

Syaifuddin. (2013). Microblogging Sebagai Pembetuk Personal Branding Akun Twitter Fahira Idris. Institut Teknologi dan Bisnis Kalbe. Jakarta.

Tamimy, Muhammad Fadhol. (2017). SharingMu Personal Branding-Mu. Jakarta: Visimedia Pustaka. 